\title{
SECULARISM IN TURKEY (1)
}

\section{- A Dilemma in Turkish Politics -}

Dr. Bülent DÂVER

Associate Professor

Faculty of Political

Sciences A n k a r a

The secularism is the result as well as the cause of Ataturk reforms carried out mainly in the years of 1922-1938. This principle, unlike the West, has been realized not by evolutionry currents and ideas of the philosophers, disseminated among the large parts of the populace during the centuries, but rather by the direct resolute action, and by the revolutionry enthusiasm, of a considerably small elite composed of bureaucrats and army officers. The Turkish intelligentsia led by Atatuirk, sought secularism as a modernizing principle, a progressive idela covering not only the political and governmental life, but a whole social and cultural milieu which was, in its very nature, dominated by superstitions, dogmas and ignorence. Those factors inhibited the people to become a modern and prosperous nation. However, very strictly applied during the years of one party rule, the principle of secularism was never meant in the eyes of its proponents as a new dogma, or a new religion to replace Islam. Instead the republican leaders were very cereful not to attack Islam as a faith. Their purpose was rather to "purify" Islam and to open the gate for a reformist islamic thought. To bring an end to the supremacy of ulema was their war-cry. Thus secularism appeareld as an anticlerical movement, a protest to the tyranny of fanaticism. Indeed in Islamic thought and system there was no place for a special clergy or superstitions.

Beginning in 1945, under the multy-party system, some easing and relaxation has been noted in governmental policies towarld religion. After 1950, with the Democrat Party at power, easing the curbs on religious liberties has reached to a point 
that some Western observers often used the term of "Islam's revival in Turkey». However this policy of giving too much credit to the conservative circles was opposed mainly by Republican Party even labeled by the revolutionary circles as a treasion to the Kemalist principles. One of the causes of the Revolution of 27 May 1960 was the desire to bring an end to the exploitation of religion for political and personal purposes.

For a foreign scholar there can be some inconsistency -if not contradiction- in the application of the principle of secularism in Turkey. For instance, the state is controlling the religious affairs, organizing it as a department of the State. Each year a great deal of money poured out from the State budget for religious affairs (1). In the realm of religious liberties there are limitations which can seem, "excessive» to a liberal minded observer. Those facts can only explained in terms of Turkey's special historical and social conditions. The students of Turkish affairs are very well aware of these specific factors. Our purpose here is to make an outline of the secularist movement in Turkey and mainly to try to give answer to some questions raised by the delicate problems of relationship between state and religion.

In our opinion, the most difficult task for Turkey's actual leaders is to make an arrangement in order to bring a broad consensus about the religion's role in a secular state there must be among the contending panties some agreement on the need of speedy modernization in one hand and to take o moderatly liberal stand on the other hand vis à vis Islam which has still many adherents. The secularization of the masses is still the great unfinished mission of the Turkish leaders. This mission requires a subtle analyssis of the situation as well as the dedication anid courage.

F.

\section{II - OTTOMAN EMPIRE AND SECULARISM}

Ottoman Empire was a theocratical state like the other turkish states who appeared on the scene of history - beginning from the 10 th till 15 th centuries. The sheria was the fundemental law for believers as well as the rulers. But few Moslem rulers in histony have made it the main business of state, as the Koran had inten-

(1) For a detailed analysis of the matter: Dr. Bülent Daver, Türkiye Cumhuriyetinde Lâiklik (The Secularism in Turkish Republic) Ankara 1955, pp. $73-78$. 
ded, to enforce God's eternal laws. Administrative criminal, civil and commercial law had almost, from the baginning of the Islamic community, been separated from the domain of sheria, though this separation was not formally and explicitly codified until the nineteen century (2).

Islam had also early reconciled itself to the separation between religion and the conduct of the state in foreign affairs once it acquiesced in the peaseful coexistence of orthodox Islamic States with Christian and heteredox Islamic nations. As Majid Khaktduri pointed out: "The principle of peaceful relationship among nations of different religions; perhaps the most revolutionary in Islamic legal theory, was for the first time embodied in a treaty signed in 1533 between Francis I of France and Soliman the Magnificent, Sultan of the Ottoman Empire (3).

\section{III - TANZIMAT}

Despitie these facts the hold of Islam on state as well as on the believers was very strong. For Islam was not only a faith, a credo, but also a legal system aiming at organizing the whole life including political, social, civil, and cultural aspects. First reaction to the Islam's pretention to administrate all the matters, covering the temporal world, came during the Tanzimat period, inaugurated in 1839 , by a ferman of the Sultan. Tanzimat's administrators saw the impossibility to conduct state affair's according to religious principles. Under the pressure thery felt obligaid to introduce western laws based not on the Holy Koran but on the modern principles which were practised in modern nations. Another breach in the orthodox Islam system has been the introduotion of public schools which were essentially secular in their nature. Furthermore along with the religious counts which were dealing with the privates cases of citizens, special secular courts were created in the Ottoman Empire. The judges appointed to those new courts were different in their manner as well as in their forrmation from their colleagues in sheria courts.

Despite those steps on the way of secularisation, Ottoman Empire was still mainly theocratic in character and outlook. Flor

(2) Halpern, The Politics of Social Change in the Middle East and North Africa. Princeton, N. Jersey, Princeton University Press, 1963. p.... 130.

(3) Majid Khadduri, "The Islamic System: Its Competition and Coexistence with Western Systems». Proccedings of the American Society of of International Law, 1954, p. 51. 
the Sultan was officially the head of all Moslems. The Constitu tion promulgated in 1876, explicitly stated that the duty of As sembly is to carry out the principles of sheria. Another article said that the religion of the State was Islam.

\section{IV - ATATÜRK'S REFORMS}

For a radical change one need to wait till Atatürk's reforms. After liberation of the country from the enemy a series of steps were taken in order to secularise the State and social life. In 1924 Caliphate and the Ministry of Religious Affairs was abolished. In 1925 Religious orders were prohibited. In 1926 a civil law was int. roduced. In 1928 with the amendment of the Constitution, the article stating that "the State's religion is Islam» has been abroga. ted. Finally the principle of secularism, was introduced in the Constitution with amendment madie in 1937. Along these legal changes came many reforms secularising the social and cultural life. Religious teaching in public scholls was suspended, public demeanor of women has been changed _ especially in big cities. The language of the prayers in mosques was made Turkish in. stead of Arabic etc...

\section{V - MULTY PARTY SYSTEM}

\section{a - Republican Party's Concessions.}

After the death of Atatürk and especially entering the multy party period the things have been changed. One of the main issues between the Republican Party which started secularism and championed it, and newly created Democratic Party, was the role of religion in Turkish life. Indeed R. P. P. (Republican Peoples Panty) itself had made certain concessions under the pressure of the opposition. R. P. P. had agreed to allow religious instruction in public scholl against parents written request. R. P. P. also permitted the opening of some religious places such as türbes (mausoleums) to the public. RPP authorized the creation of a Faculty of Theology in Ankara and the training of imams by private individuals in order to meet the well - taken objection that if no new religious leaders were trained, either Islam would die alltogether or fall into the hands of the uneducated and the covert.

\section{b - D.P In Power}

In 1950 with a landslide electoral victory the Democrats came to power. The Democrats had been eleated on a platform 
tending to be conservative, had based much of their appeal on representing the wishes of the people in implied contrast to the imposed reforms of the R. P. P. For a large part of the Democratic vote came from conservative rural areas(4). Thus some relaxation in the pressure for total secularisation of Turkish life would come during the Democratic period. The Democrats expanded the number of institutions for training imams and allowe'd them to take on a conservative tinge. In the field of the religious instruction in public (state) schools, the Democrats altered this arrangement to read that all Muslim children would recieve religious instruction, unless their parents requested in writing that the children should not recieve it. Thus religious education was made somehow compulsory taken into consideration the fact-no parent in Turkey would dare to state explicity that the religious instruction was undesirable. Furthearmore the religious education which was given only in primary schools till 1950 was extended to the secondary schools. Taking another step, on their way, the Democrats abolished the law prohibiting the use of the Arabic form of calling to prayer (Ezan). The entire country immediatly dropped the Turkish translation wich the earlier law had substituted (5).

Other areas or relaxation were more unofficial. Ramazan, the Moslem holy month, began to be celebrated more publicly. Religious publications began to reappear. The remnants of various mystic sects (dervish orders) began tentatively to show their heads, although it must be saild that the troublesome sects like the Ticanis and Nur were severely dealt with in $1950-1960$. Religious associations which had been prohibited, in any form, under thea "Law of Associations", promulgated in 1938, began to be founded and their numbers constantly increased during the years ahead. Those religious associations were bearing the names of "Association for the Contribution to the Mosques», "Association for the Needy Pupils of Koran Sshools» etc... During this period a large portion amount of government funds was used for building new mosques in cities, towns and villages. One estimates that some 5000 mosques were built between 1950 and 1960. This was approximately the same figure given by the National Ministry of

(4) Walter F. Weiker: The Turkish Revolution, 1960-1961. The Brookinks: Institution, Washington D. C., 1963, u. 8-9.

(5) See in this matter article written by Paul Stirling, "Religious Change in Republican Turkey», Middle East Journal (Autumn 1958) p. 400. 
Education, for the construction of new schools in the same period. One foreign correspondant dealing with the matter wrote»... This silent struggle for scarce ressources seem highly symbolic of the greater struggle between the forces of secularism and Islam in Turkey (6).

\section{IV - THE REVOLUTION OF 27 th MAY 1960}

The great struggle between the principle of secularism and Islam has marked a turning point with the 27th May Revolution staged by army officers.

The discontent of the Turkish army with the DP gevernment should be explained in terms of governmental policies with which the Turkish military authorities strongly disagreed. Among these policies one can state the ambivalence of DP government toward modernity and secularism as well as ultraconservative social and economic policies (7).

Indeed on May the $3 \mathrm{rd}, 1960$ general Cemal Gürsel, than Commanding General of Turkish Land Forces, sent a letter to the government through. the Minister of Defence and listed a number of steps which he thought the government must take if the political situation was to be righted. These steps, included among others, ending the exploitation of religion for political purposes.

After the coup on many accasions the members of the military Junta shared this view

In July 1961 during the "Yes Campaign» for the Constitution referandum the NUC (Committee for National Unity), published a pamphlet entiteled "Our Constitution viewed from a religious standpoint» in which in is said (8): ... To refrain from relying evien partly on religious grounds for idetermining the social, economic, political and legal foundation of the state is useful to those who wish to exploit it for political or personal ends».

In the eyes oh the members of NUC the chief task for Turkey was to return to the rapid an drastic reform policies of secu-

(6) David Hotham, "Turks Turn Again to Religion», The Times, February
$23,1960$.

(7) Frederic Frey, The Turkish Political Elite p. 390.

(8) Cumhuriyet, July 2, 1961. 
larism which was the hallmark of the period when Atatürk guided the nation.

Thus Article 2 of the 1961 Constitution proclaims that «The Turkish Republic is a nationalistic, democratic secular and social state». Article 153 stipulates that "No provision of this Constitution shall be construed or interpreted as rendering unconstitutional the Reform Laws which aim at raising the Turkish society to the level of contemporary civilization and at safeguanding the secular character of the Republic, which were in effect on the date this Constitution was adopted by popular vote».

Finally Constitution strictly forbids the exloitation or abuse or religion under the threat of penalities. Article 19 states that: "No person shall be allowed to exploit and abuse religion or religious feelings or things considered sacreld by religion in any manner whatsover for the purpose of political or personal benefit, or for gaining power, or for even partially basing the fundamental social, economic, political and legal order of the State on religious dogmas. Those who violate this prohibition, or those who induce others to do so shall be punishable under the partinent laws. In the case of associations and political parties the former shall be permenently closed down by order of authorized courts and the latter by order of the Constitutional Court» (9).

There will be argument in Turkey for many years about whether the Democratic Party period was one of the betrayal of secularism, the exploitation of religion, the restoration of freedom of worship, or the beginning of a new period of "Islamic Revival». "The pertinent fact is that the Democrats and the RPP made the interpration of secularism an evergrowing issue. It dovetailed with other issues and servad to add the fuel to a fire which will continue to smoulder» (10).

According to F. Frey, Menderes and his lieutenants actually neither wanted nor could afford a religious reaction which would endanger the very foundations of the secular republic. The Democratic Party, though willling a mild religious revival, was basioally quite modern in its top personnel and quite commited in its own way to a continuation of modernization, even while trying to make political capital out of the religious issue» (11).

(9) See also Turkish Penal Law, article 163.

(10) WEIKER, op cit. sh. 9.

(11) F. Frey, on cit. p. 180. 
Some people can angue of course that a heightened interes in religion is perfectly compatible with secularism and moderm zation. Robinson, for example asserts that by 1960, despite a rel: gicus conservative element of politically significant size it $n$ longer endangered the secular republican state. Islam itself hal been undergoing a subtle transformation even on the village le vel. Economic and social incentive material well - being, innowa tion, the machine, commerce and social change no longer apper red as challenges to religion. An accomadation between folk - Islam and modern life was in fact taking place (12).

But the committment of the DP to secularism and moderni zation was substantially quite different from the Kemalist model

Secularism was one of the most central pillars of Atatürk re volution. Secularism was interpreted by Atatürk to mean exclusion of heavy religious influence from public life, and in some cases meant discouraging private religious observance as well. After Ata türk's death and especially since the rise of opposition parties in 1946 the role of religion in Turkish life has become one of the most important public issues (13).

During the Democrat's easing of previous restraints has hal. ped undermine the secularist spirit to the benefit of Islam, not. the enlightened progressive Islam but the same old obscurantist. fatalistic type which has dominated the Turkish masses since time immemorial (14).

Kemalist secularism, indeed, had a different and much more comprehensive meaning in Turkey than in the West. Atatürk's secularism did not limit itself to the separation of religious from political affairs. It also aimed at liberating the society from the holld of Islam, and to bring about a new type of free individual. It was a nationalist, scientific-minded, ant $\mathrm{i}$-traditionalist and anti-clerical secularism. Therefore the critics of Turkish secularism may be theoratically right in that the old conception of the state subordinated to religion had been replaced by the concep tion of the religion bound to the state, and both conceptions violated the principle of secularism (15).

(12) Robinson, The First Turkish Republic, p. 205. See also Lerner and Robinson, "Swords and Plougshares», World Politics, vol. XII October 1966 pp. $19-22$

(13) Weiker, The Turkish Revolution 1960-1961, p. 4.

(14) K. Karpat, Turkey's Politics, p. 288.

(15) Karpat, op. cit., p. $271-277$. 
However given the fatalistic and obscurrantist nature of the religious beliefs among the Turkish masses, a mere separation between the state and religion would certainly not be enougfh to create a modern seciety based on national and scientific thinking. Alternatives open to the Kemalist cadres in the 1920's were either to reform Islam radically enough to become o progressive force-Atatïrk unsuccessfully tried it in some cases-or to restrict religious liberties to a greater extent than in secular Western States. In view of the enormous difficsulties involved in the first alternative, it was only natural that the latter course was chosen (16).

But we must carefully indicate that Atatïr, the most farreaching of the secularists, did not openly challenge the islamic- faith, nor did any of the political leaders who came after him. Their struggle was not with the İslamic credo, but rather with the supertitions and fanaticism which were borrewed from other faiths, and finally damaged the religion. As W. C. Smith wrote "Every honest Türk felt necessary in their deep conscience those restrictions on clerical and fanatical forces» (17).

\section{VII - SOME REMARKS}

After this quick review dealing with the origin and evolution of the principle of secularism in Turkey we can conclude that despite Atatürk's reforms, a gap remains between the existing social, cultural norms and revolutionary legal norms. In Turkey, officially the most secular of İslamic countries, religion has not ceased to be a political issue and the likelihood is that it will yet provoke much more conflict. Honest, democratic balloting makes the Turkish peasant the kingi-pin of the electorate, yet he has been intellectually and socially more isolated from the Atatürk revolution, and has changed less than any other part of the population. Appeals to religion may yet become a major substitute for eliciting or retaining rural support, especially if the almosit steady increase of the economic benefits to the peasant should cease, either because Turkish planners find good cause to reallocate the distribution of ressources, or else because the economy fatters. The growth of religious brotherhoods (dervish orders) with hallo-

(16) Ergun Özbudun, The Role of the Military in Recent Turkish Politics. P. 17.

(17) W. C. Smith Modern Türkiye Dini Bir Reforma mı Gidiyor, Ankara İlâhiyat Fakültesi Dergisi, 1953, sayı 1. sh. 13. 
wed traditional names but highly modern purposes during the past few years, has been increasingly reported in Turkish news. papers and exposed in court trials. A marriage of convenience between them and certain political parties which attack the re forms of Atatürk by no means excluded (18.)

\section{SUMMARY AND CONCLUSION}

1. Secularism in Turkery has appeared as a movement which aims at curbing of the supremacy of religion once very strong in political and social life. The State has controlled the religious af fairs even has organized it as a Department of the general administration. A great number of religious men are civil servants and getting salary from the goverment budget. Certainly this is incompatible with the principle of secularism as understood and applied in the Western countries. Turkish reformers knew that secular State was a kind of "Cesarism». But to adopt a complete secularism at this stage was meant, in due course to endanger the reforms and to restore the old theocratic state with all fanaticism and superstitions. Because the religious elements were so strong in the social structure of Turkey that for the State it was almost impossible to be able to apply a broad secularism and to secure a complete religious freedom to all.

2. Turkish law makiers do not depend anymore on the viza of the sheria in making the partinent laws for a society which is undergoing a deep social and economic change and which desires to catch up with the speed of modiern nations.

3. During the republican era a national educational system was ereated inspiring not from the religious dogmas but from the scientific values of the modern times. For a whille religious education was suspended in public schools, for there were not enough able teachers of religion. Most of the hedjas were almost ignorant people unawere of the knowledge and necessities of the modern sosiety. Entering the mult-party system era, Turkish leaders have tolerated the religious teaching in public schools under the government auspices and control.

This also may seem irreconciliable, in the eyes of Westernens, with the principle of secularism which forbids religious teaching

(18) Manfred Halpern, op. cit. p. 152. 
in public (satete) schools. In our opinion, this too, is an excepti-

$\lg$ the newsience le re-

hich $\mathrm{g}$ in afdmiants is and hat onal public order measure, dictated solely by necessities. In the future when the majority of the people attains a degree of maturity enabling them to understand the real meaning of religion, and when dogmas as well as the superstitions wither away, then the time will come to adopt a complete secularism. The religious affairs then will be the business of private associations and institutions.

4. Though curbing in some instances the freedom of religion in behalf of the secular state, the Turkish reformers never intended to create a new religion or to supresis Islam, banning all moral and religious values from the society. Rather Turkish reformers aimed at the serting up of a new «milieu» for free development of religious liberties. Some limitations were either inspired by nationalistic feelings (such as the Turkish prayers in mosques) or by the strong desire to oppose the obsourantism and idleness as in the case of the abolition of the religious orders.

5. In the new era with, A.P. (Justice Party) in power one can assume that the easing of some limitations on religious matters may be expected in the future. But this time, upon the experience on the 1960 Revolution, A.P. will be very careful in handling religious issues and certainly will not give concessions to the fanatical circles. There are already some positive signs in this direction, last year the goverment had recalled the president of religious affairs on the ground that he was «backing» the Nurcu sect.

Secularisation of the political leadership seems now almost well established in Turkey. In the domain of social life religious marriage and polygamy is still reigning in Turkey in many areas -especially in rural parts- despite the reforms laws which are penalizing such acts. There are some politicians -even among the reformist and socialist parties- handling religious isseues in electoral campaigns.

But vieweld by a general perspective of the situation we can pretend that Turkey now has passed the critical point and is on the high road of modernization.

The speedy economic and social change will certainly have impact on the mind and behavior of the leaders as well as the people. New social and cultural values will inevitably guide the future turkish politics and contribute to the happy solution of the dilemma.

(1) This paper have been presented to the IPSA's İstanbul Round Table Meething of 28 May. - 2 June 1967. 
Ali Fuat Başgil, Din ve Lâiklik (Religion and Secularism). İstanbul, 1955

Niyazi Berkeș, The Development of Secularism in Turkey. Montreal, McGill University Press, 1964.

Bülent Dâver, Türkiye Cumhuriyetinde Lâiklik (Secularism in Republican Turkey). Ankara, 1955.

F. W. Frey, The Turkish Political Elite. Cambridge, Mass, M. I. T. Press, 1965.

Manfred Halpern, The Politics of Social Change in the Middle East and North Africa. Princeton, New Jersey, Princeton Üniversity Press, 1963.

Uriel Heyd, "Islam in Modern Turkey», Journal of Royal Central Asian Society, Vol. XXXIV, July-October, 1947 Pp. 299-308.

Kemal H. Karpat, Turkey's Politics: The Transition to a Multy - Party System. Princeton, Princeton University Press, 1959.

Bernard Lewis, "İslamic Revival in Turkey», International Affairs, Vol. XXVIII, Tanvary, 1952, sh. $38-48$.

Ergun Özbudun, The Role of the Military in Recent Turkish Politics. Harvard University Center for International Affairs, Occasional Papers in International Affairs, Number 14, 1966.

Çetin Özek, Türkiye'de Lâiklik (Secularism in Turkey) İstanbul, 1962.

Howard A. Reed, "Secularism and Islam in Turkish Politics», Current History, Vol XXII, June, 1957, sh. 333-338.

Howard A. Reed, "The Religious Life of Modern Turkish Muslims» in R. M. Frye (ed.) Islam and West, Gravenhage: Mouton, 1957, pp. 108 148.

Howard A. Reed, "Revival of Islam in Secular Turkey» Middle East Journal Vol. VIII, Summer , 1954, pp. 627- 282.

R. D. Robinson, The First Turkish Republic. Cambridge, Harvard, 1963.

Dankwart A. Rustow, Politics and Islam in Turkey, 1920-1955», in Frye (ed.) Islam and the West, pp. 69-107. Grovenhage Mouton, 1957.

W. C. Smith, «Modern Türkiye Dini bir Reforma mı Gidiyor?» Ankara Illâhiyat Fakiultesi Dergisi, 1953 sayı 1.

Paul Stirling, "Religious Change in Republican Turkey», Middle East Journal, Autumn, 1958, p. 400.

Lewis V. Thomas, «Recent Developments in Turkish Islam», Middle East Journal, Vol, VI, Winter, 1952, pp. $22-40$.

Tarık Zafer Tunaya, Islâmcılık Cereyanı (The movement of Islamism) Istanbul, Baha Matbaası, 1962. 